\title{
Two-tube multiplex real-time reverse transcription PCR to detect six human coronaviruses
}

\section{Dear Editor,}

Coronaviruses are enveloped positive-strand RNA viruses with $27-33 \mathrm{~kb}$ genomes. These viruses are classified into four genera, namely Alphacoronavirus, Betacoronavirus, Gammacoronavirus, and Deltacoronavirus (Adams and Carstens, 2012). The Middle East respiratory syndrome coronavirus (MERS-CoV), which was first and only recently identified in the Middle East, belongs to the genus Betacoronavirus (Zaki et al., 2012). The human coronaviruses HCoV-NL63, HCoV-229E, SARS$\mathrm{CoV}, \mathrm{HCoV}-\mathrm{OC} 43$, MERS-CoV, and HCoV-HKU1 are associated with high-morbidity respiratory distress, including acute respiratory tract infection, pneumonia, and bronchiolitis (Gaunt et al., 2010; Zaki et al., 2012; Lu et al., 2014). Of these, HCoV-NL63, HCoV-229E, HCoV$\mathrm{OC} 43$, and $\mathrm{HCoV}-\mathrm{HKU} 1$ are frequently isolated from patients, and are globally distributed, although prevalence varies with time and geographical region (Geng and Tan, 2013). On the other hand, an outbreak of SARS between 2002 and 2003 afflicted approximately 8,000 people, with 774 deaths (Stadler et al., 2003).

Timely diagnosis is critical in managing coronavirus infections, and in tracing possible sources. Many early diagnostic technologies relied on cumbersome and insensitive methods such as serology, virus cultures, and antigen detection. Molecular diagnostic tests have since confirmed that coronaviruses are causative agents of respiratory distress, and have allowed identification to species. Today, reverse-transcription polymerase chain reaction (RT-PCR), real-time PCR with melt curve analysis, and probe-based real-time RT-PCR are routinely used to detect human coronaviruses in nasopharyngeal swabs (Theamboonlers et al., 2007; Gaunt et al., 2010). However, these techniques have limited sensitivity or are low throughput, precluding rapid screening of large numbers of samples.

In this study, we developed a two-tube multiplex realtime RT-PCR assay for sensitive and specific detection of all known human coronaviruses. Total nucleic acids were extracted from $100 \mu \mathrm{L}$ samples using QIAamp Viral RNA Mini Kit. Primer sets (Table 1) quoted from the references were modified based on the Nucleotide Col- lection Database (National Center for Biotechnology Information, Bethesda, MD, USA) for our study using Primer Premier 5.0. Different primer and probe combinations were evaluated in preliminary experiments. Based on these experiments, primers for NL63, 229E, and SARS were grouped into one triplex reaction, while those for MERS, OC43, and HKU1 were grouped into another (Table 1). Viral targets were amplified on a CFX96 real-time PCR system (Bio-Rad, USA) using One Step RT-PCR Enzyme Mix (TaKaRa, Japan) in 25 $\mu \mathrm{L}$ reactions containing $12.5 \mu \mathrm{L} 2 \times$ PCR buffer, $0.5 \mu \mathrm{L}$ RT enzyme mix, $0.5 \mu \mathrm{L}$ Taq enzyme mix, $2 \mu \mathrm{L}$ template DNA, as well as primers and probes added from $10 \times$ mixtures. Final concentrations are listed Table 1. Reactions consisted of $5 \mathrm{~min}$ reverse transcription at $42{ }^{\circ} \mathrm{C}$, $10 \mathrm{~s}$ denaturation at $95^{\circ} \mathrm{C}$, and 40 cycles at $95^{\circ} \mathrm{C}$ for 10 $\mathrm{s}$ and $62^{\circ} \mathrm{C}$ for $45 \mathrm{~s}$. Human RNase $P$ gene was amplified as internal control. Data were analyzed by univariate statistics and binary logistic regression. $P$ values $<$ 0.05 were considered statistically significant.

Preliminary experiments indicate that the two-tube multiplex assay was internally specific for each coronavirus. Importantly, cross-reactivity was not observed with influenza A virus, influenza B virus, parainfluenza virus $1-4$, respiratory syncytial virus, metapneumovirus, adenovirus, bocavirus, rhinovirus, echovirus, mumps virus, measles virus, and Staphylococcus aureus.

Sensitivity was assessed using in vitro transcripts of all six coronaviruses, which were obtained using a T7 large-scale RNA production system (Promega, WI, USA). These transcripts were serially diluted 10 -fold, and amplified in triplicate by two-tube multiplex RTPCR and by previously established monoplex RT-PCR. We found that $C t$ values did not differ significantly between monoplex and multiplex reactions (data not shown). PCR products were cloned into pGEM-T Easy and confirmed by sequencing. Detection limits were determined using samples containing one virus, or all six viruses in equal proportion. Standard curves were generated from samples containing one virus by plotting $C t$ values against the log of copies/ $\mu \mathrm{L}$ (Supplementary Figure $\mathrm{S} 1)$. The high sensitivity of the assay was confirmed using synthesized RNA standards at 10 copies/reaction.

To obtain additional performance data and explore 
Table 1. Primers for two-tube multiplex real-time RT-PCR.

\begin{tabular}{|c|c|c|c|c|c|}
\hline Virus (target) & Target gene & Primer & Sequence & $\begin{array}{l}\text { Concentration } \\
(\mathrm{nmol} / \mathrm{L})\end{array}$ & Reference \\
\hline \multicolumn{6}{|c|}{ Multiplex PCR \#1 } \\
\hline \multirow{3}{*}{ HCoV-NL63 } & \multirow{3}{*}{ Nucleoprotein } & Forward & AGGACCTTAAATTCAGACAACGTTCT & 100 & \multirow{3}{*}{$\begin{array}{l}\text { Theamboon- } \\
\text { lers et al., } \\
2007\end{array}$} \\
\hline & & Reverse & GATTACGTTTGCGATTACCAAGACT & 50 & \\
\hline & & Probe & $\begin{array}{l}\text { FAM-TAACAGTTTTAGCACCTTCCTTA } \\
\text { GCAACCCAAACA-TAMRA }\end{array}$ & 25 & \\
\hline \multirow{3}{*}{ HCoV-229E } & \multirow{3}{*}{ Nucleoprotein } & Forward & CGCAAGAATTCAGAACCAGAG & 50 & \multirow{3}{*}{$\begin{array}{l}\text { Adapted from } \\
\text { Theamboon- } \\
\text { lers et al., } \\
2007\end{array}$} \\
\hline & & Reverse & GGCAGTCAGGTTCTTCAACAA & 75 & \\
\hline & & Probe & $\begin{array}{l}\text { HEX-CCACACTTCAATCAAAAGCTCCC } \\
\text { AAATG-TAMRA }\end{array}$ & 25 & \\
\hline \multirow{3}{*}{ SARS-CoV } & \multirow{3}{*}{ Nucleoprotein } & Forward & TGGACCCACAGATTCAACTGA & 50 & \multirow{3}{*}{$\begin{array}{l}\text { Adapted from } \\
\text { Theamboon- } \\
\text { lers et al., } \\
2007\end{array}$} \\
\hline & & Reverse & GCTGTGAACCAAGACGCAGTAT & 50 & \\
\hline & & Probe & $\begin{array}{l}\text { CY5-TAACCAGAATGGAGGACGCAATG } \\
\text { G-BHQ2 }\end{array}$ & 25 & \\
\hline \multicolumn{6}{|c|}{ Multiplex PCR \#2 } \\
\hline \multirow{3}{*}{ HCoV-OC43 } & \multirow{3}{*}{ Nucleoprotein } & Forward & GCTCAGGAAGGTCTGCTCC & 50 & \multirow{3}{*}{$\begin{array}{l}\text { Theamboon- } \\
\text { lers et al., } \\
2007\end{array}$} \\
\hline & & Reverse & TCCTGCACTAGAGGCTCTGC & 25 & \\
\hline & & Probe & $\begin{array}{l}\text { FAM-TTCCAGATCTACTTCGCGCACAT } \\
\text { CC-TAMRA }\end{array}$ & 25 & \\
\hline \multirow{3}{*}{ MERS-CoV } & \multirow{3}{*}{ Nucleoprotein } & Forward & GGCACTGAGGACCCACGTT & 50 & \multirow{3}{*}{$\begin{array}{l}\text { Adapted from } \\
\text { Lu et al., } \\
2014\end{array}$} \\
\hline & & Reverse & TTGCGACATACCCATAAAAGCA & 50 & \\
\hline & & Probe & $\begin{array}{l}\text { CY5-CCCCAAATTGCTGAGCTTGCTCC } \\
\text { TACA-BHQ2 }\end{array}$ & 25 & \\
\hline \multirow{3}{*}{ HCoV-HKU1 } & \multirow{3}{*}{ Replicase 1b } & Forward & СCTTGCGAATGAATGTGCT & 50 & \multirow{3}{*}{$\begin{array}{l}\text { Adapted from } \\
\text { Dare et al., } \\
2007\end{array}$} \\
\hline & & Reverse & TTGCATCACCACTGCTAGTACCAC & 375 & \\
\hline & & Probe & $\begin{array}{l}\text { HEX-TGTGTGGCGGTTGCTATTATGTT } \\
\text { AAGCCTG-TAMRA }\end{array}$ & 25 & \\
\hline
\end{tabular}

possible applications, we tested the ability of two-tube multiplex RT-PCR to detect viral RNA in monkeys experimentally infected with known titers of MERS-CoV (Yao et al., 2014). The MERS-CoV strain hCoV-EMC was generously provided by Drs. Fouchier and Haagmans at Erasmus Medical Centre, The Netherlands, and was propagated and titered in Vero cells. Swabs from infected monkeys were collected according to published methods (Yao et al., 2014) by Professor Qin Chuan at Institute of Laboratory Animal Sciences, Chinese Academy of Medical Sciences. Viral RNA was detected in nasal, throat, and anal swabs within two days of infection, after which point viral RNA was most abundant in throat swabs (Supplementary Table S1). Notably, multiplex PCR was able to distinguish virus from Vero cell cultures at different titers (Supplementary Figure S2).

In addition, we tested the performance of two-tube real-time RT-PCR against whole blood and pharyngeal swabs collected in 2015 in Guangdong Province, China, from a Korean patient with suspected MERS (Lu et al., 2015). The virus was detected in all specimens (Supplementary Table S1). Results were comparable to in-house monoplex RT-PCR reactions ( $\mathrm{Lu}$ et al., 2014).

Moreover, we assessed the ability of two-tube multiplex RT-PCR to monitor HCoV-HKU1 propagation in human airway epithelial cells (Zhu et al., 2015). The $\mathrm{HCoV}-\mathrm{HKU} 1$ stock was provided by the National Institute for Viral Disease Control and Prevention, Chinese Center for Disease Control and Prevention. Copies of HCoV-HKU1 RNA increased with time, peaking at $96 \mathrm{~h}$ post-inoculation (Supplementary Table S2), in line with in-house monoplex reactions (Dare et al., 2007).

Finally, clinical performance was evaluated using 346 nasopharyngeal swabs obtained in 2014 from children under 14 years who were hospitalized with acute respiratory infection. This study was approved by the Institutional Review Boards of the Chinese Center for Disease Control and Prevention, and written informed consent 
Table 2. Detection of coronavirus in 346 clinical samples.

\begin{tabular}{|c|c|c|c|}
\hline \multirow{2}{*}{ Target } & \multicolumn{2}{|c|}{ Two-tube multiplex real-time RT-PCR } & \multirow{2}{*}{$\begin{array}{l}\text { One-tube multiplex real-time RT-PCR } \\
\text { with inline electrophoresis } \\
\text { Positive samples (\%) }\end{array}$} \\
\hline & Range of $C t$ values & Positive samples (\%) & \\
\hline HCoV-NL63 & $25-33.5$ & $5(1.46)$ & $5(1.46)$ \\
\hline HCoV-229E & $26-34$ & $10(2.89)$ & $10(2.89)$ \\
\hline SARS-CoV & & 0 & 0 \\
\hline HCoV-OC43 & $26-35$ & $6(1.73)$ & $5(1.46)$ \\
\hline MERS-CoV & & 0 & 0 \\
\hline HCoV-HKU1 & $28-34.5$ & $3(0.87)$ & $1(0.29)$ \\
\hline Co-infection ${ }^{\mathrm{a}}$ & & $3(0.87)$ & $3(0.87)$ \\
\hline Total & $25-35$ & $24(6.94)$ & $21(6.1)$ \\
\hline
\end{tabular}

Note: ${ }^{\mathrm{H}} \mathrm{HCoV}-\mathrm{NL} 63$ and HCoV-229E $(n=1), \mathrm{HCoV}-\mathrm{OC} 43$ and HCoV-229E $(n=2)$.

was obtained from parents or guardians of all patients. As shown in Table 2, two-tube multiplex real-time RTPCR detected viruses in 24 (6.94\%) samples, of which five $(1.46 \%)$ were infected with NL63, and $10(2.89 \%)$ were infected with 229E. Six samples $(1.73 \%)$ tested positive for OC43, and HKU1 was detected in three $(0.87 \%)$ samples. There were no differences between two-tube multiplex real-time RT-PCR and a previously established, one-tube multiplex RT-PCR assay with inline electrophoresis (QIAxcel, Qiagen) (Niu et al., 2014). In addition, co-infection was detected by both assays in three patients $(0.87 \%)$, of whom one was co-infected with NL63 and 229E, while the other two were co-infected with OC43 and 229E (Table 2). Infection was confirmed (data not shown) by in-house monoplex real-time PCR (Lu et al., 2012). Notably, one case of OC43 and two cases of HKU1 were detected by two-tube multiplex RT-PCR, but not by one-tube multiplex RT-PCR with inline electrophoresis. Nested RT-PCR and gene sequencing confirmed results from two-tube multiplex RTPCR (data not shown), highlighting its potentially higher sensitivity for these viruses.

Real-time RT-PCR is an established, rapid and effective method to detect multiple viral pathogens of the respiratory tract (Dare et al., 2007; Gaunt et al., 2010; Lu et al., 2012). We have developed a sensitive and specific real-time RT-PCR assay to detect all six human coronaviruses. Its ability to monitor HKU1 replication in cultures of human airway epithelial cells, to quantitatively measure viral RNA in monkeys experimentally infected with MERS, and to detect MERS in a human patient was demonstrated . In addition, the assay was used to assess disease burden and epidemiology of coronaviruses among hospitalized patients with acute respiratory infection, and able to detect co-infection. Finally, the assay re- quires significantly less sample than monoplex real-time RT-PCR. Thus, the assay will be widely used in coronavirus research.

\section{FOOTNOTES}

The authors thank Dr. Bart Haagmans and Ron Fouchier at Erasmus Medical Center, Rotterdam, the Netherlands for providing MERS-CoV isolate hCoV-EMC/2012. We also thank Dr. Qin Chuan at Institute of Laboratory Animal Sciences, Chinese Academy of Medical Sciences for providing swabs from rhesus monkeys challenged with MERS-CoV. This work was supported by grants from the State Megaproject for Infectious Disease Research of China (2014ZX10004001-002, 2013ZX10004101, 2013ZX10004805-002). The funding agency did not participate in study design, data collection and analysis, decision to publish, or preparation of the manuscript. The authors declare that they have no conflict of interest. All the animal tests comply with Chinese Center for Disease Control and Prevention laboratory animal management approach and the requirement of animal welfare. Written informed consent was obtained from parents or guardians of all patients.

Supplementary figures/tables are available on the website of Virologica Sinica: www.virosin.org; link.springer.com/journal/12250.

Peihua Niu ${ }_{1 \text {, Jun Shen }}^{2 \#}, \mathrm{Na} Z \mathrm{Zhu}^{1}$, Roujian Lu${ }^{1}$, Wenjie $\operatorname{Tan}^{1 \otimes}$

1. Key Laboratory of Medical Virology, Ministry of Health, National Institute for Viral Disease Control and Prevention, Chinese Center for Disease Control and Prevention, Beijing 102206, China. 
2. Children's Hospital of Fudan University, Shanghai 200032 , China.

$\triangle$ Correspondence:

Phone: +86-10-58900878, Fax: +86-10-58900878,

Email: tanwj28@163.com

\#These authors contributed equally to this work.

ORCID: 0000-0002-5963-1136

Published online: 25 January 2016

\section{REFERENCES}

Adams MJ, Carstens EB. 2012. Arch Virol, 157: 1411-1422.

Dare RK, Fry AM, Chittaganpitch M, et al. 2007. J Infect Dis, 196: $1321-1328$.
Gaunt ER, Hardie A, Claas EC, et al. 2010. J Clin Microbiol, 48: 2940-2947.

Geng H, Tan W. 2013. Sci China Life Sci, 56: 683-687.

Lu R, Wu J, Niu P, et al. 2015. Chin J Exp Clin Virol, 29: 193-195. (In Chinese)

Lu R, Yu X, Wang W, et al. 2012. PLoS One, 7: e38638.

Lu X, Whitaker B, Sakthivel SK, et al. 2014. J Clin Microbiol, 52: 67-75.

Niu P, Zhang C, Lu R, et al. 2014. Chin J Prev Med, 48: 416-419. (In Chinese)

Stadler K, Masignani V, Eickmann M, et al. 2003. Nat Rev Microbiol, 1: 209-218.

Theamboonlers A, Samransamruajkit R, Thongme C, et al. 2007. Intervirology, 50: 71-77.

Yao Y, Bao L, Deng W, et al. 2014. J Infect Dis, 209: 236-242.

Zaki AM, van Boheemen S, Bestebroer TM, et al. 2012. N Engl J Med, 367: 1814-1820.

Zhu N, Niu P, Zhao Y, et al. 2015. Chin J Exp Clin Virol, 29: 80-82. (In Chinese) 